\title{
DIRECT EFFECTS OF SOYBEAN SEED VIGOR ON WEED COMPETITION ${ }^{1}$
}

\author{
MARCOS ALTOMANI NEVES DIAS², TAIS LEITE FERREIRA PINTO ${ }^{3}$, VITOR HENRIQUE VAZ MONDO², \\ SILVIO MOURE CICERO ${ }^{4}$, LETICIA GOMES PEDRINI ${ }^{2}$
}

\begin{abstract}
Seed vigor is one of the factors that determines the speed and uniformity of seedling emergence and initial plant growth, which are crucial aspects in the competition against weeds. The objective of this study was to verify the direct effects of soybean seed vigor on weed competition and grain yield. A field experiment was conducted with three seed lots of the "Conquista" cultivar, previously characterized by physiological tests as having high, intermediate and low vigor. The experiment was divided into weeded and unweeded plots with six treatments. Crop plant height, weed dry mass accumulation and crop grain yield data were recorded. Seed vigor did not affect plant height and grain yield. Plants which developed from seeds with high and intermediate vigor showed the best results for competition against weeds, reducing weed dry mass accumulation. Plants which developed from high vigor seeds give the best results for grain yield for both weeded and unweeded treatments.
\end{abstract}

Index terms: Glycine max L., physiological potential, grain yield, crop interference.

\section{EFEITOS DIRETOS DO VIGOR DE SEMENTES DE SOJA NA COMPETIÇÃO COM PLANTAS DANINHAS}

\begin{abstract}
RESUMO - O vigor das sementes é um fator que determina a velocidade e uniformidade de emergência de plântulas e o crescimento inicial das plantas, que consistem em aspectos cruciais na competição com plantas daninhas. Assim, os objetivos neste estudo foram verificar os efeitos diretos do vigor de sementes de soja sobre a competição com plantas daninhas e rendimento de grãos. Um experimento de campo foi conduzido na Universidade de São Paulo, Piracicaba, Brasil, com três lotes de sementes do cultivar "Conquista", previamente caracterizados por meio de testes fisiológicos como de alto, intermediário e baixo vigor. O experimento foi dividido em parcelas com e sem controle de plantas daninhas, compondo seis tratamentos. Os dados de altura das plantas de soja, acúmulo de massa de matéria seca de plantas daninhas e de produtividade de grãos foram obtidos. $\mathrm{O}$ vigor das sementes não afetou a altura das plantas e o rendimento de grãos de soja neste estudo. As plantas desenvolvidas a partir de sementes de alto e médio vigor apresentaram os melhores resultados na competição com plantas daninhas, proporcionando redução do acúmulo de massa de matéria seca destas. Plantas provenientes do lote de sementes de alto vigor apresentam maior rendimento de grãos, tanto em parcelas com controle, como nas sem controle de plantas daninhas.
\end{abstract}

Termos para indexação: Glycine max L., potencial fisiológico; rendimento de grãos; interferência da cultura.

\footnotetext{
${ }^{1}$ Submitted on 19/08/2010. Accepted for publication on 02/01/2011.

${ }^{2}$ Undergraduate student. University of São Paulo, Piracicaba, Brazil. marcosaltomani@hotmail.com; leticiapedrini@hotmail.com.
}

${ }^{3}$ Graduate student, Crop Science Department, University of São Paulo, 


\section{INTRODUCTION}

Weed control is very important in soybean production since losses due to weeds are one of the main prejudicial factors (Ferrell et al., 2009). Growers should be aware that for consistent weed management there are many ways to maintain the weed population at a low interference level, including : sowing density, row spacing, the hybrid or cultivar planted, soil seed bank management, cleanliness of irrigation ditches, use of certified seeds and herbicide rotation, to cite some examples (Bowman, 1997; Smith et al 2000).

Crop interference of weed growth and reproduction is an effective way to suppress weeds (Jordan, 1993; Dias et al. 2010). Variations on competition ability can be observed among varieties (Callaway, 1992; Jordan, 1993; Khan and Hassan, 2007) and are correlated with a capacity for rapid resource uptake by the crop, supported by characteristics such as higher leaf area index and more extensive root tissue (Callaway, 1992). Crop varieties and hybrids may vary substantially in their response to weed competition and it is known that those which grow faster are more competitive.

Another factor that affects initial plant growth is related to seed vigor. Characteristics such as a lower germination, higher susceptibility of seeds and seedlings to stresses and plants with slow, lower and irregular growth or with less root development, are associated with seeds having a low physiological potential (Marcos Filho, 2005). In general, seed vigor includes characteristics that determine the potential for a rapid and uniform emergence of normal seedlings under a wide range of environmental conditions (Marcos Filho, 2005).

Vanzolini and Carvalho (2002) and Kolchinski et al. (2005), studying the relationship between soybean seed vigor and field performance, observed differences in initial plant growth and grain yield from plants originating from seed lots with different seed vigor. Conflicting effects of seed vigor on grain yield can be found in the literature. Tekrony et al. (1989) declared that seed vigor affects initial crop growth but the differences should decrease during successive developmental stages, disappearing by the end of the crop cycle. Therefore, in a stress situation, such as with weed competition, these differences tend to be higher among plants originating from seeds with high and low seed vigor.

Crop development is directly related to efficient resource capture and use and to plants' competitive ability. Therefore, the initial rapid and uniform growth of plant populations, which could be obtained by using high quality seeds, should directly affect soybean-weed competition and crop productivity.

Differences in initial crop growth related to seed vigor are described in the literature for rice (Oryza sativa L.) (Hofs et al., 2004; Melo et al., 2006; Mielerzski et al., 2008), black oats (Avena strigosa Schreb.) (Schuch et al., 2000), corn (Dias et al., 2010) and soybeans (Vanzolini and Carvalho, 2002; Kolchinski et al., 2005; Kolchinski et al., 2006; Schuch et al., 2009). In a context where crop yield is correlated with efficient resource uptake, including water, nutrients and solar radiation, faster initial growth will probably result in a better competitive ability and higher crop grain yields.

The objective of this research was to study the direct effects of soybean seed vigor on resistance to stress caused by weed competition and also to verify effects on grain yield. This could demonstrate to growers the importance of using certified and high quality seeds for growing soybeans.

\section{MATERIAL AND METHODS}

Soybean seeds of the 'Conquista' cultivar from three different lots having the same seed size seed, produced in the 2007/2008 season, were used for this study. The tests described below were used to characterize the seed lots and verify the feasibility of using these lots to carry out the experiment.

Seed moisture content: determined using two samples per lot, previously weighed, and oven dried at $105{ }^{\circ} \mathrm{C} \pm 3{ }^{\circ} \mathrm{C}$ for 24 hours. Later, the sample dry weights were measured and the initial moisture content of each sample calculated (Brasil, 1992).

Germination: using four replications of 50 seeds per lot, sown on rolls of blotting paper. The amount of water corresponded to 2.5 times the substrate weight. The samples were placed in an incubator at $25 \pm 1{ }^{\circ} \mathrm{C}$. The first count of normal seedlings occurred five days and the second count seven days after sowing (Brasil, 1992).

Seedling and hypocotyl length: determined according to Nakagawa (1999), with five replications of 20 seeds under the same conditions as the germination test but in the dark. The seeds were positioned with the hilum pointing downwards since the rolls were placed vertically 
in the incubator. Five days after sowing, the hypocotyl and seedlings lengths were measured in millimeters and the mean results expressed in centimeters.

Electrical conductivity: with four replications of 50 seeds per lot, previously weighed, and imbibed in a recipient containing 75 milliliters of deionized water, placed in incubator at $25{ }^{\circ} \mathrm{C} \pm 1{ }^{\circ} \mathrm{C}$, for 24 hours. Afterwards, the electrical conductivity was determined using a Digimed CD-20 device and the results expressed in $\mu \mathrm{mho} . \mathrm{cm}^{-1} \cdot \mathrm{g}^{-1}$.

Accelerated ageing: with four replications of 50 seeds per lot distributed in a uniform layer on a screen, inside plastic boxes containing 40 milliliters of deionized water at the bottom. The boxes were covered and maintained in an incubator, at $42{ }^{\circ} \mathrm{C} \pm 1{ }^{\circ} \mathrm{C}$, for 96 hours. Afterwards, the seeds were submitted to a germination test (Brasil, 1992) and the normal seedlings counted after five days.

Seedling emergence: observed in plastic trays (34 x $23 \times 7 \mathrm{~cm}$ ), with four replications of 50 seeds per lot on a sand substrate. The water volume was adjusted to $60 \%$ of the substrate retention capacity. The trays were covered and kept at room temperature with the count made seven days after sowing.

The field experiment was carried out during the 2008/2009 growing season at Piracicaba, SP, Brazil ( $22^{\circ} 42^{\prime}$ S; $47^{\circ} 38^{\prime} \mathrm{W} ; 546 \mathrm{~m}$ above sea level) on a Rhodic Kandiudalf soil. The area had previously been planted with corn; the plots were hand-sowed on December $12^{\text {th }} 2008$, at a rate of 20 seeds. $m^{-1}$ and thinned fifteen days later to a plant population of 355,000 plants.ha ${ }^{-1}$. Soil applications of $12 \mathrm{~kg} \cdot \mathrm{ha}^{-1} \mathrm{~N}, 60 \mathrm{~kg} \cdot \mathrm{ha}^{-1} \mathrm{P}$ and 60 $\mathrm{kg} . \mathrm{ha}^{-1} \mathrm{~K}$ were made. The total amount of rainfall and mean temperature during the crop cycle were 567.2 $\mathrm{mm}$ and $24.3{ }^{\circ} \mathrm{C}$, respectively. Sprinkler irrigation was available. The treatments consisted of three levels of seed vigor in weeded and unweeded plots, arranged in a randomized block design with four replications. Each plot contained four rows, $0.45 \mathrm{~m}$ apart and five meters long, and four meters of the two central rows were used for evaluations.

Seeds were inoculated with Bradyrhizobium sp. strains at a concentration of 600,000 cells per seed, and treated with a fungicide (carbendazim, $30 \mathrm{~g}$ of active ingredient and thiram, $70 \mathrm{~g}$ of a.i. per $100 \mathrm{~kg}$ of seeds), an insecticide (thiametoxan, $35 \mathrm{~g}$ of a.i. per $100 \mathrm{~kg}$ of seeds), cobalt at 3 g.ha $^{-1}$ and molybdenum at 30 g.ha $^{-1}$. The crop received the same insect and disease management for all plots. The weeds were managed with pre-emergence herbicides (imazaquim 100 g.ha-1, clopyralid 0,5 L. ha ${ }^{-1}$ and trifluralin 100 g.ha ${ }^{-1}$ ) and also with one operation of manual weeding, being careful not to disturb the soil and crop in the plots with a weed control treatment. Field evaluations of crop height, weed dry mass accumulation and crop yield were made as follows:

Crop height: ten plants per plot at the V2 (second trifoliate) and V6 (sixth trifoliate) crop stages were randomly chosen. The heights were measured by raising the youngest leaf to the highest level and measuring the distance from the soil in centimeters.

Weed dry mass accumulation: when the soybeans were mature, all weedy material (aerial parts) was collected at random from a $0.45 \mathrm{~m}^{2}$ area between the central plot rows which did not receive any weed control. The samples were oven dried at $65{ }^{\circ} \mathrm{C}$ for 72 hours and weighed to measure dry mass accumulation.

Crop yield: the treatments were harvested on April $16^{\text {th }}, 2009$, for weeded plots and on May $5^{\text {th }}, 2009$, for unweeded plots, due to the longer soybean maturation caused by weed competition. All the pods, except from the border rows, were harvested and threshed in a combine harvester. Grain moisture content was determined as for seeds. Afterwards, the values were adjusted to $12 \%$ moisture content to determine grain yield.

Seed characterization data were analyzed in a completely randomized design. Plant height and yield data were analyzed by an ANOVA ( $F$ test) in a $3 \times 2$ factorial design and means were compared by Tukey's test (5\%). The data of weed dry mass accumulation were graphically analyzed by standard mean error (SME).

\section{RESULTS AND DISCUSSION}

The seed characterization values show a significant difference between lot vigor, with lot 1 showing a higher vigor than lots 2 and 3, but with no differences in germination (Table 1). It was possible to do this experiment owing to the possibility of directly attributing the field results to differences in seed vigor.

Seed vigor did not affect plant height for either crop stage analyzed (two and six leaves) or for the weeded or unweeded situations (Table 2). Kolchinski et al. (2005) associated soybean seed vigor with biometrical parameters, such as leaf area index and plant dry mass. However, no direct correlation between seed vigor and plant height was observed in this study. 
TABLE 1. Preliminary tests for the characterization of seed lots: germination (G; \%); accelerated ageing (AA;

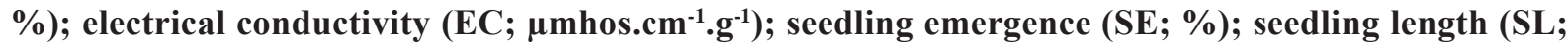
cm); hypocotyl length (HL; cm); seed moisture content (SM, \%).

\begin{tabular}{cccccccc}
\hline Lots & G $(\%)$ & AA $(\%)$ & $\begin{array}{c}\mathrm{EC}(\mu \mathrm{mho} \\
\left.\mathrm{cm}^{-1} \cdot \mathrm{g}^{-1}\right)\end{array}$ & SE $(\%)$ & SL(cm) & HL(cm) & SM $(\%)$ \\
\hline 1 & $89 \mathrm{a}^{1}$ & $94 \mathrm{a}$ & $82,8 \mathrm{a}$ & $91 \mathrm{a}$ & $24,9 \mathrm{a}$ & $8,3 \mathrm{a}$ & 7,9 \\
2 & $84 \mathrm{a}$ & $92 \mathrm{a}$ & $89,0 \mathrm{ab}$ & $86 \mathrm{ab}$ & $21,3 \mathrm{~b}$ & $7,3 \mathrm{~b}$ & 7,7 \\
3 & $82 \mathrm{a}$ & $86 \mathrm{a}$ & $93,6 \mathrm{~b}$ & $81 \mathrm{~b}$ & $20,5 \mathrm{~b}$ & $6,8 \mathrm{~b}$ & 7,3 \\
\hline $\mathrm{CV}(\%)$ & 9,94 & 6,23 & 5,78 & 6,39 & 7,22 & 8,39 & \\
\hline
\end{tabular}

${ }^{1}$ Means in the same column followed by the same letter did not show differences according to Tukey's test at the $5 \%$ significance level.

TABLE 2. Plant height and grain yield of soybean crop in weeded (WWC) and unweeded plots (WTWC), composed of high (H), intermediate (I) and low (L) seed vigor lots.

\begin{tabular}{ccccc}
\hline \multirow{2}{*}{ Treatment } & Lot & \multicolumn{2}{c}{ Height $(\mathrm{cm})$} & \multirow{2}{*}{ Yield $\left.^{*} \mathrm{Kg}^{2} \mathrm{ha}^{-1}\right)$} \\
\cline { 3 - 4 } & & V2 & V6 & $1133 \mathrm{~b}$ \\
\multirow{2}{*}{ WTWC } & $\mathrm{H}$ & $27,0 \mathrm{a}^{1}$ & $59,8 \mathrm{a}$ & $811 \mathrm{~b}$ \\
& $\mathrm{I}$ & $26,7 \mathrm{a}$ & $60,5 \mathrm{a}$ & $654 \mathrm{~b}$ \\
\hline \multirow{2}{*}{ WWC } & $\mathrm{L}$ & $25,4 \mathrm{a}$ & $60,5 \mathrm{a}$ & $2331 \mathrm{a}$ \\
& $\mathrm{H}$ & $17,0 \mathrm{~b}$ & $41,1 \mathrm{~b}$ & $2304 \mathrm{a}$ \\
& $\mathrm{I}$ & $16,7 \mathrm{~b}$ & $43,6 \mathrm{~b}$ & $2050 \mathrm{a}$ \\
\hline
\end{tabular}

${ }^{1}$ Means in the same column followed by the same letter did not show differences according to Tukey's test at the $5 \%$ significance level.

Soybean plants in unweeded plots showed a higher vertical growth caused by etiolation due to the presence of weeds (Table 2). This effect has been described by Ballare and Casal (2000), and occurs when the light that reaches a plant population is reflected from plant to plant, signaling competition and stimulating their growth towards the sunlight. In addition, the initial effect of preplant herbicides in weeded plots may have delayed crop growth; however, no differences were observed between lots, indicating that vigor did not affect this parameter.

Weed dry mass accumulation (Figure 1) was significantly reduced at different seed vigor levels. Increases of around $70 \%$ were observed when comparing high and medium vigor lots to the low vigor lot. During the crop cycle, the most important weed species in the unweeded plots were: Panicum maximum Jacq., Cenchrus echinatus L., Ipomoea sp., Xanthium strumarium L., Digitaria sp. and Cyperus rotundus L.

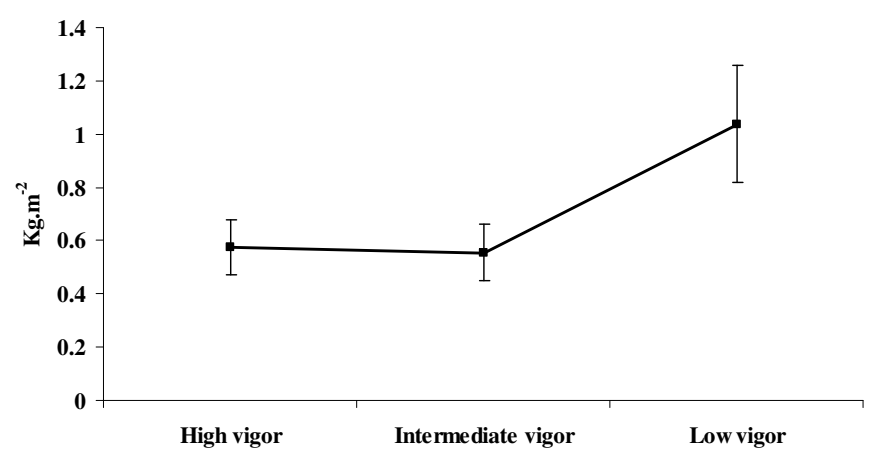

FIGURE 1. Weed dry mass accumulation $\left(\mathrm{kg}^{\mathrm{m}} \mathrm{m}^{-2}\right)$ for three different levels of soybean seed vigor of the 'Conquista' cultivar in unweeded plots. Bars correspond to the Standard Mean Error (SME). 
In a comparison of varieties, Wicks et al. (1986) also found differences of around 82\% for weed suppression between twenty winter wheat (Triticum aestivum L.) varieties. Supporting these findings, Khan and Hassan (2007) reported varietal differences in competitive ability by the same crop. Balbinot and Fleck (2005) have declared that the selection of genotypes showing appropriate morphological and physiological characteristics could increase crop ability to compete against weeds. Ferrell et al. (2009) said that most of the yield reduction in soybeans is due to weed competition, which occurs during the first six weeks after sowing, and reinforced the importance of seed vigor, which affects the plants mainly in the primary growth stages.

Although there were grain yield differences between the seed lots for weeded and unweeded treatments, they were not statistically significant (Table 2). For both weeded and unweeded treatments, the grain yield of the lot with high seed vigor surpassed that of the lot with low seed vigor, whereas the lot with intermediate seed vigor gave intermediate results. However, the yield range among the high and low seed vigor lots, in the unweeded plots ranged from $1130 \mathrm{~kg}^{-h^{-1}}{ }^{-1}$ to 650 kg.ha-1 $(73 \%)$, and in the weeded plots with from $2500 \mathrm{~kg}^{-h^{-1}}$ to $2030 \mathrm{~kg} \cdot \mathrm{ha}^{-1}(23 \%)$. These results clearly show that under stress from weed competition, soybean plants developing from high vigor seeds show a better performance than those from low vigor seeds. Similar results on the effects of seed vigor on grain yield were observed by Kolchinski et al. (2005), with differences of around 30\%, and by Mattioni et al. (2009) with differences of around $20 \%$, for soybean and cotton, respectively.

Thus, the results of this study show it is possible to correlate the competitive ability of soybean plants with seed vigor resulting in changes in weed development in the field. In addition, high vigor seeds can give higher grain yields.

\section{CONCLUSIONS}

Soybean crop height and grain yield were affected by the presence of weeds but were not significantly altered by seed vigor. However, under stress from weed competition, plants originating from low vigor seeds yielded considerably less. Those plots sowed with low vigor seeds had a higher weed dry mass accumulation.

\section{ACKNOWLEDGMENTS}

The authors thank FAPESP (São Paulo State Research Foundation) for a scholarship grant for the first author.

\section{REFERENCES}

BALBINOT JR., A.A.; FLECK, N.G. Manejo de plantas daninhas na cultura de milho em função do arranjo espacial de plantas e características dos genótipos. Planta Daninha, n.23, p.415-421, 2005.

BALLARÉ, C.L.; CASAL, J.J. Light signals perceived by crop and weed plants. Field Crops Research, v.67, p.149-160, 2000.

BOWMAN, G. Steel in the field: a farmer's guide to weed management tools. Sustainable agriculture network handbook series 2. Beltsville: National Agriculture Library (USDA), 1997. 128p.

BRASIL. Ministério da Agricultura e Reforma Agrária. SecretariaNacionaldeDefesa Agropecuária. Departamento Nacional de Produção Vegetal. Coordenação de Laboratório Vegetal. Regras para Análise de Sementes. Brasília, DF, 1992. 365p.

CALLAWAY, M.B. A compendium of crop varietal tolerance to weeds. American Journal of Alternative Agriculture, v.7, n.4, p.169-180, 1992.

DIAS, M.A.N.; MONDO, V.H.V; CICERO, S.M. Vigor de sementes de milho associado à matocompetição. Revista Brasileira de Sementes, v.32, n.2, p.93-101, 2010.

HOFS, A.; SCHUCH, L.O.B.; PESKE, S.T.; BARROS, A.C.S.A. Emergência e crescimento de plântulas de arroz em resposta à qualidade fisiológica de sementes. Revista Brasileira de Sementes, v.26, n.1, p.92-97, 2004.

FERRELL, J.A.; MacDONALD, G.E.; BRECKE, B.J. Weed management in soybeans. University of Florida, Institute of Food and Agricultural Sciences. Available at: < http://edis.ifas.ufl.edu/pdffiles/WG/WG01000.pdf>. Accessed 14 mar. 2010.

JORDAN, N. Prospects for weed control through crop interference. Ecological Applications, n.3, p.84-91, 1993.

KHAN, I.A; HASSAN, G. Competitive ability of various wheat cultivars with wild oats. In: AFRICAN CROP SCIENCE CONFERENCE PROCEDINGS, 8., 2007. El-Minia: African Crop Science Society, 2007, p.19011904. http://www.acss.ws/Upload/XML/Research/514. pdf

KOLCHINSKI, E.M.; SCHUCH, L.O.B.; PESKE, S.T. Vigor de sementes e competição intra-específica em soja. Ciência Rural, v.35, n.6, p.1248-1256, 2005.

KOLCHINSKI, E.M.; SCHUCH, L.O.B.; PESKE, S.T. 
Crescimento inicial de soja em função do vigor das sementes. Revista Brasileira de Agrociência, v.12, p.163-166, 2006.

MARCOS FILHO, J. Fisiologia de sementes de plantas cultivadas. Piracicaba: FEALQ, 2005. 495p.

MATTIONI, F; ALBUQUERQUE, M.C.F; MARCOS FILHO, J. Vigor de sementes sobre o desempenho de plantas e a produção de algodoeiro. In: CONGRESSO BRASILEIRO DO ALGODÃO, 7., 2009, Foz do Iguaçu. Anais... Campina Grande: Embrapa Algodão, 2009, p.1851-1859. http://www.cnpa.embrapa.br/produtos/ algodao/publicacoes/cba7/VIICBA_anais/PTS_P.305.pdf

MELO, P.T.B.S.; SCHUCH, L.O.B.; ASSIS, F.N.; CONCENCO, G. Comportamento de populações de arroz irrigado em função das proporções de plantas originadas de sementes de alta e baixa qualidade fisiológica. Revista Brasileira de Agrociências, v.12, n.1, p.37-43, 2006.

MIELEZRSKI, F.; SCHUCH, L.O.B.; PESKE, S.T.; PANOZZO, L.E.; PESKE, F.B.; CARVALHO, R.R. Desempenho individual e de populações de plantas de arroz híbrido em função das sementes. Revista Brasileira de Sementes, v.30, n.3, p.86-94, 2008.

NAKAGAWA J. Testes de vigor baseados no desempenho das plântulas. In: KRZYZANOWSKI F.C.; VIEIRA R.D.; FRANÇA NETO J.B. (Ed.). Vigor de sementes: conceitos e testes. Londrina: ABRATES, 1999. p.1-24.

SCHUCH, L.O.B.; NEDEL, J.L.; ASSIS, F.N. Vigor de sementes e análise de crescimento de aveia preta. Scientia Agricola, v.57, n.2, p.305-312, 2000.

SCHUCH, L.O.B.; KOLCHINSKI, E.M.; FINATTO, J.A. Qualidade fisiológica da semente e desempenho de plantas isoladas em soja. Revista Brasileira de Sementes, v.31, n.1, p.144-149, 2009.

SMITH, R.; LANINI, W.T.; GASKELI, M.; MITCHELL, J.; KOIKE, S.K; FOUCHE, C. Weed management for organic crops. Davis: University of California 2000. 5p. (Publication n.7250).

TEKRONY, D.M.; EGLI, D.B.; WICKHAM, D.A. Corn seed vigor effect on no-tillage field performance: II. Plant growth and grain yield. Crop Science, n.29, p.1528-1531, 1989.

VANZOLINI, S.; CARVALHO, N.M. Efeito do vigor de sementes de soja sobre o seu desempenho em campo. Revista Brasileira de Sementes, v.24, n.1, p.33-41, 2002.

WICKS, G.A.; RAMSEL, R.E.; NORDQUIST, P.T.; SCHMIDT, J.W.; CHALLAIAH. Impact of wheat cultivars on establishment and suppression of summer annual weeds. Agronomy Journal, v.78, p.59-62, 1986. 